\title{
The Study of Theft in Iran and Federal Criminal Law
}

\author{
Saeed Ekradi ${ }^{1} \&$ Saleh Ghaffari Cherati ${ }^{2}$ \\ ${ }^{1} \mathrm{PhD}$ student of criminal law and criminology, Department of Law, Elm Farhang, Tehran, Iran \\ ${ }^{2} \mathrm{PhD}$ student of criminal law and criminology, Department of Law, University of Mazandaran, Mazandaran, Iran \\ Correspondence: Saeed Ekradi, PhD student of criminal law and criminology, Department of Law, Elm Farhang, \\ Tehran, Iran. E-mail: Saeed.ekradi@gmail.com
}

Received: June 5, 2017

Accepted: July 1, $2017 \quad$ Online Published: August 30, 2017

doi:10.5539/jpl.v10n4p174

URL: https://doi.org/10.5539/jpl.v10n4p174

\begin{abstract}
One of the oldest crimes against property, usually with a tough punishment for the perpetrators in the religions and communities has been theft. In explanation of the nature and causes of theft different theories have been presented, and this is indicative of multiple factors in the occurrence of theft. Totally theft isn't a specific type of behavior, but is a widely multiple behavior. Namely, in creating it does not merely one cause, in general, different factors such as family disputes, economic, and low income, addiction, immigration, education level, young age, and so are effective on theft (theft). The purpose of this paper is to examine the definition and types of theft under Iranian and federal law as well as contributing factors in the commission of theft and discovering interrelationships between sociological, psychological and physiological variables in incidence, prevalence and frequency and authorities planning to develop strategies to deal with this crime.
\end{abstract}

Keywords: criminal law, theft, Iran, federal

\section{Introduction}

Today, with the development of communities and more advanced and complex societies, the relationships between people and society are becoming increasingly sophisticated and widespread. In such a condition, the human beings in terms of their nature and temperament, always and at all times are trying to comfort, well-being and social and material progress. These efforts are done in different ways. A group move to achieve wealth and prosperity within the boundaries of law and respect for the rights of others, meanwhile a group also do not spare any effort to achieve their goals and even break the norms and laws and violation of the rights of others and accept apply these acts as strategies and methods to achieve their goal that such behaviors throughout the history have been led to social rules and punishment systems.

Among major crimes in numerous societies including is theft. This crime is one of the oldest crimes in a society which has undergone many changes and the form of it form at different times and in different societies has been changed.

The different factors and issues causing tend to theft at the present time have been more complex than in the past and therefore it is difficult to deal with it than before and there are problems in this way. In this paper, in the first speech the definitions and types of theft, according to federal law and the law of Iran are addressed and in the second speech, statistics (data) available about the theft in Iran and America are expressed.

First Speech: The definition of theft and its variants:

\section{First Topic: The Definitions of Theft}

In the United States the theft means the illegal taking and possession of the other's property with any value with intent to permanently deprive other of the person from the taken means (instrument) or its value.

According to Article 267 of the Islamic Penal Code "Theft (Theft) is the stealing property belonging to the other." Thus, the theft in addition to the general elements of the crime has specific elements:

\footnotetext{
- $\quad$ Stealing

- movable property

- $\quad$ belonging the property to other
} 
Thus, realization of theft as a crime is required to act an action, such as theft (removing), snatch, picking up, taking and seizing property of another without the consent of the owner or possessor of the property (Goldoozian, 2007: 445) and snatching as the linchpin of theft is the occupation and establish and catching (grasping) a property without the knowledge and consent of the owner or holder.

So, the prerequisite for stealing is this that a thief secretly or openly, but surprising the owner of the property, without attracting attention and unlike her/his desire and consent attempts to capture the other property. For example, if at a store the buyer pay a 500 Tomans banknote for purchased goods, but the seller wrongly considers the mentioned banknote as one thousand and give an extra money to buyer, for buyer who knowingly and with intent to seize receive additional money and go out from a store such an act does not constitute elements of snatching and theft.

Similarly, unwanted and out of free will submission of the property from its owner realizes the element of snatching in theft. So in the case of in which the delinquent takes a property with intent on stealing from one minor and insane, despite the formal submission of property, since the minor and the insane doesn't have discrimination and diagnostics power for evaluating his/her behaviors and their actions, the French courts such consider such surrenders as involuntary and establish it as snatching and theft (Atashpour, 1997).

What about the criminal history of theft in Iran is noteworthy is that with the approval of the General Penal Code adopted in 1304 [in Persian date] (1925 AD), in the Iranian penal code, theft without being defined, for which the penalty was determined. In addition, Article 222 Penal Code Act of adopted in 1352 [in Persian date] (1973 AD) that exactly is the same Act, the Penal Code, adopted in 1304 [in Persian date] (1925 AD), without reference to the definition of theft has determined that: when theft is not a comprehensive regulation on the law, but coupled (closed) to all five following conditions, the offender's penalty is imprisonment. After the Islamic Revolution with changes in the political structure of the country, some rules were also changed. Those can be named a Public Penal Code Act, which adopting Hoodud and qisas, was replaced by the law. Including rules on Hoodud and Qisas (retaliation in kind) law was changed by mentioned rule. Among rules which on Hoodud and Qisas (retaliation in kind) law has been changed are the rules on the theft that in the articles of 212 to 218 mentioned law, the order was placed about the theft in which the material is 212 to 218 law, had been sentence (order). Article 212 of Hoodud and Qisas (retaliation in kind) law it was written that: theft is that man secretly steals another man's property. According to Article 215 of the same law, the theft in the case led to Hadd (penalty) which has some conditions including theft must be done in secret. The comparison of article 212 defining the theft in which adverb (indicating) secretly had come, with Article 215 mentioning the conditions of theft led to Hadd (penalty), including the condition of secrecy theft had been raised, raising the question, whether the adverb (indicating) secretly in the theft definition are constituent elements of a crime such a way that had been mentioned in article 212 or is considered among theft condition leading to Hadd (penalty), such a way that had been in the article 215? Some authors of criminal law had (and have) the opinion that the secretly adverb (indicating) in defining theft is among the Hadd (penalty) conditions and it can't be considered in the row of theft constituent elements. Considering the above question and the ambiguity in the definition of theft by comparing Article 215 of Hoodud and Qisas (retaliation in kind), the legislator in 1370 [in Persian date] (1991 $\mathrm{AD}$ ) with the adoption of the Islamic penal code, which must be run tentatively for five years, made some changes in some provisions of the Hoodud and Qisas (retaliation in kind) including slight deformation in the definition of theft. A legislator in Article 197 of the Islamic Penal Code Act of 1370 [in Persian date] (1991 AD) decreed: theft is to steal someone else secretly. As can be seen, the legislator has retained the secretly adverb (indicating) in the definition of theft, but in the Article 198 of the same law refers to the theft conditions leading Hadd (penalty), secretly adverb (indicating) has been removed from the conditions and thus the idea that secretly as conditions of theft leading Hadd (penalty) has been rejected, and actually stated that secretly adverb (indicating) must be considered among constituent elements of theft. However, some of the authors of criminal law believe that the legislative act on keeping secretly adverb (indicating) in the definition of theft is not true and the mentioned adverb (indicating) should be noted among theft conditions leading Hadd (penalty). Therefore, this question evokes what is the decision about thefts which done openly and publicly and under what title the perpetrators are punished? After a five-year pilot period of the Islamic penal code adopted in 1370 [in Persian date] (1991 AD) and revealing some weaknesses and questions about the mentioned law, the legislature again in 1375 [in Persian date] (1996 AD) made a number of changes and reforms in some cases, especially about the provisions of theft and opened a new chapter, which previously did not exist under the title of theft and snatching another person's property and in articles 651 to 667 ruled different types of theft and snatching another person's property attached sales, education and concealing stolen property as well as repeat theft.

The remarkable thing in the Islamic Penal Code Act of 1375 [in Persian date] (1996 AD), presenting of snatching 
another person's property along the title of theft. The study and comparison of the mentioned articles in Chapter XXI of the Islamic Penal Code Act of 1375 [in Persian date] (1996 AD), it is possible to create doubts. For example, in Article 665 of the mentioned law, we read: Everyone snatches (steals) other's property and his/her act is not subject to theft, will be condemned to imprisonment from six months to a year, and if the result of theft process is a damage entered to the victim, he/she will be convicted to its penalty as well. The question is, how is it possible to someone steals else's property, but his/her act does not subject to theft title? On the other hand, the legislator in Article 657 of the same law provides: Whoever commits the abduction of another's property through, snatching the bag and pickpocketing, etc., will be sentenced to imprisonment for one to five years and 74 lashes. The other question is that according to the above article, has the legislator in Article 66 which we just mentioned it, repeated or another thing has been intended? Finally, one of the major problems of the Islamic Penal Code on the theft, has been solved in the new law approved (adopted) in 1392 [in Persian date] (2013), such that in Article 197 of the old Code was said the theft: stealing (snatching) the property of others secretly and mentioning adverb "secretly" in the text of the law, has encountered the judges and lawyers with many problems because it did not include explicit armed thefts and bag snatching (Islamic Penal Code).

The new Islamic Penal Code has fixed this problem. This means that, Article 267 of the new Islamic Penal Code defining the theft stated: "theft is snatching property belonging to others."

The second topic: the types of theft:

According to federal law, theft includes five types:

1) Larceny theft: the federal investigative committee, as well as Uniform Crime Report (UCR) has defined this theft as illegal picking of property belonging to others, with examples such as bicycle theft, theft of laptop theft, in which case we have started to theft as well. There is no force feature in this type of theft.

2) Shoplifting: The main factor determining the rate of theft from a shop is the items for sale. Its reason is also quite obvious. For example, the rate of theft in furniture store is much lower than a pharmacy or stores that sell luxury goods and so. Among these goods, tobacco (particularly cigarette), a variety of clothing from the sport stores to children's clothes store, cosmetics and perfumery, pharmaceutical can be referred, such as painkillers without a prescription, prescribed drugs for congestion, chest or nasal and birth control medications (analgesics with elements that can be used in the preparation of some drugs and chest congestion drugs using to facilitate drug manufacturing in high volume when mixed with other drugs) (Rezaei, 2014).

The acronym CRAVED represents the main causes of theft from stores and shopping centers (shoplifting). Its letters mean respectively: Concealable (the ability to hide), Removable (being movable), Available (availability), Valuable, being attractive and Disposable. The latest one, namely Disposable (the ability to use) is the most important determinant of the amount of goods stolen from stores (Clark, 2009: 26).

This type of theft is the most common type of theft and statistics show, the thieves are trapped are only one third of the original thieves. This means in practice, twice arrested thieves, men and women do shoplifting, without revealing their secret.

The amount of annual loss that found in department stores is an average of 8 million dollars.

And among every thirty theft in large stores, only 9 thieves fell by trapped, less than thirty percent. Therefore, actually more than $70 \%$ thieves of stores remain hidden from the eyes of the officials (Salahi, 2010).

But sellers do not pay much attention to the problem of theft from shops. In fact, they have specific motives for this neglect as well. For example: stolen property will be eliminated from the list of goods tax, prosecuting thieves take time and requires enough power, if someone mistakenly arrested may subsequently proceeded to the action, if the owner constantly report theft (stealing) from his/her shop will be famous and become notorious (in some cases, especially in case of small stores located in commercial areas, fear of retaliation by thief may also stop operators from reporting the crime to the police) (Rahmat, 2011).

Investigating cases of shoplifting, the FBI has reached the following conclusions:

1) The well-dressed people (whether male or female) do theft (steal) more than poor people

2) Eight percent of all women referred to the store, certainly lift one or two items, while this ratio in men is five percent

3) Very few thieves steal less than two or three items

4) Usually those are arrested who have stolen more than ten items. These people show their clumsiness with this method 
Formerly, this type of theft was considered a type of mental illness and it was naming "Cleptomanie" or love to theft. Now psychiatrists reject this idea claiming that: those with this disease (i.e. Cleptomanie) do not attempt to theft only in the stores, but snatch (pick) things in the office, workplace, friends' home, and even in their home from the pockets of relatives. Of course, it is possible that the among stores thieves, there are people with "Cleptomanie" too, but certainly all of them do not suffer from this disease. For example, it has become apparent that many of these petit larcenies from shops are done by people who in their personal life are dignified, honest and even sacrificed individuals (Shambayati, 2013).

In this regard, before the Islamic revolution in Iran, this abominable fashion had been common and Kayhan newspaper released a shameful report as " petit larceny as new fun for distinguished women " that while relying on police investigations of Tehran, it has been pointed out that $95 \%$ of thieves from stores in Iran are women and $90 \%$ of them also had no need for money, just for the sake of proving cleverness or resort theft (stealing) to luxury!

Similarly, recently the newspapers in their events page quoted thieves wrote that: "We sense spiritual enjoyment from theft (stealing) and often after the theft in department stores we again put stolen objects in place a few days later!" According to psychologists, such confessions indicate moral and psychological deviations of their owner (Kayhan newspaper, 1974).

Burglary: this type of theft requires illegal entry which force does not need to enter and does not consider entering the home and may be enter into force at the office or warehouse.

3) Motor vehicle theft: motor vehicle as defined by the UCR, are those move on the ground, not on the water and not on rail and of course do not include agricultural implements and aircraft. But also include cars, motorcycles, trucks, buses and snowplows and does not include theft for joy riding that is temporary picking.

The vehicle theft in the European countries is more common than other thefts. The reason is the certain attitudes and behavior emerged after the two world wars of the past in Europe and as a result, which young people, in general, violate ethical principles and do not respect social laws and rules, especially with respect to ownership of private interest. These young people, because often need vehicle for fun and pleasure, snatch the first vehicle that could be appropriated, and use it to travel and fun or sell it and spend its money on their racquet and orgy (Hossein Nejad).

As a result, European countries, especially France, the rate of stolen vehicle has been expanded year by year. So that the statistics related this country show, by ten years after the Second World War, the stolen motor vehicles rate in this country has been seven times.

4) Pick pocketing: Under Iran's Islamic penal code the theft includes two types of Hadd and Tazir, that the Hadd of theft is run under Article 268 of the current time law and fourteen conditions exist for it, and in the absence of one of these conditions, theft is considered as Tazir and which Tazir theft itself consists of various types:

1) Government documents theft by the trustee or other: Article 545 Islamic penal code

2) Government documents burglary: Article 546 IPC

3) Historical and cultural property theft: Article 559 IPC

4) Night armed collective theft closed threaten or abuse with aggravating qualities: Article 651 IPC

5) Theft closed to persecution or armed thief: Article 652, Islamic Penal Code

6) Tazir theft (Non-belligerence): 653 of the Islamic Penal Code

7) Tazir night mass (collective) theft with possessing weapons: Article 654 of Islamic Penal Code

8) Bag-snatching - Pickpocketing: Islamic Penal Law Article 657

9) Theft in areas subject to natural disasters and devastating events and car accident: Islamic Penal Law Article 658

10) Public equipment and facilities theft: Article 659 of the Islamic Penal Law

11) Unauthorized use of water, electricity, telephone and gas, Islamic Penal Law Article 660

12) The simplest type of Tazir theft with the minimum penalty and unconditional, has been in the Islamic Penal Law Article 661 forecasted

13) Achieving or hiding or accepting stolen property, 662 of Islamic Penal Law 
14) Public theft of property: Article 665 Islamic Penal Law

15) Stealing (theft) water from the vineyards or orchards or groves (Palm trees), 684 of Islamic Penal Law

16) Stealing (theft) military objects and property by the military: Article 88, 89, 90 of the Penal Code offenses of Armed Forces

17) Theft of recording offices documents and armed forces record: Article 91 of the said law (Statistical Yearbook of Statistical Center of Iran).

\section{Second Speech: Prevalence of Theft in Society Today (Statistics)}

The figures used in this article have been achieved by the direct utilization of all types of crime in different centers and their implementation. According to UCR in 2008, 10 million financial crimes have been occurred that almost 2.3 of financial crimes have been larceny. The highest rate of reported financial crime has been in the poorest families in America, that of course this is possible because upper-income households have no incentive to report theft or because of less protected homes in the slums, so the rate of theft in the poor class I greater (Federal law).

In addition, according to UCR figures adult male living in city do the highest rate of theft. The exception for this is theft of motor vehicles which done mostly by teenagers. In the Latin America burglary has the highest rate and a large part arrests motivated for drug theft and finally can be stated that about 80 percent of all crimes reported to police in America is related to theft (Langroodi, 1988).

Also, according to statistical figures presented by the United Nations and some countries of the world, crimes against property accounted for half of all crimes done by adults. The comparison of theft rate in several countries in 1982 reflects the content of the following table.

Table 1. The number of financial crimes committed in five countries (America, England, Germany, France and Japan)

\begin{tabular}{ccccc}
\hline America & England & Germany & France & Japan \\
\hline 11571500 & 2522850 & 2775777 & 2002800 & 1233901 \\
\hline
\end{tabular}

In Iran, according to provided figures (statistics) a significant percentage of criminals by theft are counted in country's prisons statistics. So that in 1987 in our country' (Iran) theft percentage has been equal to 18.2 percent that following the drug related crime by 62.1 percent, is the highest rate (Criminology).

During the years 2004 to 2006 the statistics indicate a growing number of thieves, so that in 2004 about 11.3 and in 200514.4 percent and only in first six months of 2005, 13 percent and in 2012, 30 percent of prisoners in the prisons of the country have been thieves.

The investigation of the crime statistics from a macro perspective in Iran indicates a rising trend in recent years (Ghorban Hosseini, 1992).

\section{Conclusion}

Theft is accompanied by costly results and the private sector to provide its own security, is trying by using new and advanced security systems and workforce (such as guards) protect itself against the probable damages. In addition to these direct costs, the private sector should pay indirect costs as well that most important ones are:
A) Move to safer places, which can be costly
B) Avoid spending time outside home
C) Increased willingness to certain insurance, such as theft insurance
D) Reduced price of homes placed in crime neighborhood
E) Decreased investment due to the impact of crime on the increase in risk (hazard)
F) Reduced quality of life due to intimidation

On the other hand, the government with public sector given the task of community security must through spending on things such as police, retraining and education, etc. try in order to reduce crime in the society. In the meantime, it is obvious that spending by the government in criminal matters causes reduced share of other costs such as education, health or development, which represents a lost opportunity cost caused by security costs. 
On the other hand, the commission of any crime requires the cost of labor and capital that is directed towards it. Therefore, the second part of the costs of crime is when it arises. And finally, after the crime also numerous costs are resulted that some of them are related to victims, such as the loss of physical and human capital, and very important of it is created in the time of arrest the criminals, such as costs related to court and jail.

In addition, other long-term costs can be outlined for the families of the victims and perpetrators in terms of its effects in the future.

Thus, the potential costs of crime can be summarized as follows:

1) All the opportunity costs of time allocated to crime (by the perpetrators, victims or surveillance and maintenance systems)

2) Direct costs of security, police

3) The direct costs of the private sector

4) Impact on other markets, including the labor market

5) Impact on the quality of life of households

6) Loss or destruction of property and individuals

7) Loss of the victims and their future interests

8) Costs which maintenance systems of offenders (prison) bear

9) The long-term and future impact on offenders and victims' families

As a result the more social control and police cooperation between families, friends and neighbors the less theft rates. Since the theft more than anything else depends on opportunity, even if the target is not very attractive, even if the thief is very cautious. Such results require the prevention of theft crime and about the theft situational prevention seems to be more effective than other methods of prevention.

\section{References}

Atashpour, H. et al. (1997, July). A look to theft. Journal of education reform, 2(29).

Clarck, R. V. (2009). The prevention of crime, robbing stores, translators: Mehdi, Moghimi, Hamid Jaryani, University of Police, First Edition.

Goldoozian, I. (2007). specific criminal law (13th ed.). Tehran University Press.

Hossein Nejad, M. (n.d.). Investigating the causes of economic crime in Iran using integrated data model. Journal of Management and Budget, (95).

Hosseini, G., \& Asghar, A. (1992). criminology and theft crime detection. Tehran Jihad University Press.

Langroodi, M. J. (1988). Law terminology. Ganj-e Danesh (Knowledge treasure) Publications.

Rahmat, M. R. (2011). Crime prevention through architecture and urbanism (2nd ed.). Mizan Publication.

Ranjbar, A. A. (2014). The causes of increased theft and ways to reduce it. Correctional Journal, (143).

Rezaei, M. (2014). The causes and factors of theft among prisoners of Arak city, Arak Islamic Azad University, a master's thesis.

Salahi, J. (2010). juvenile delinquency.

Shambayati, H. (2013). juvenile delinquency.

\section{Copyrights}

Copyright for this article is retained by the author(s), with first publication rights granted to the journal.

This is an open-access article distributed under the terms and conditions of the Creative Commons Attribution license (http://creativecommons.org/licenses/by/4.0/). 